\title{
A population genetic analysis of chloroplast DNA in wild populations of Prunus avium L. in Europe
}

\author{
APARAJITA MOHANTY*, JUAN PEDRO MARTÍN \& ITZIAR AGUINAGALDE \\ Departamento de Biología Vegetal, Escuela Técnica Superior de Ingenieros Agrónomos, \\ Universidad Politécnica de Madrid, Ciudad Universitaria, 28040-Madrid, Spain
}

\begin{abstract}
A population genetic study of chloroplast DNA was carried out in 23 wild populations of Prunus avium sampled from several European deciduous forests. An analysis of approx. 9\% of the chloroplast genome detected mostly insertion-deletion mutations and one point mutation. In all, 16 haplotypes were detected. Six haplotypes were shared by two or more populations and 10 were unique. One haplotype was present in 21 of the 23 populations and 161 of 211 individuals, which probably indicates its ancient origin. The level of population subdivision, using unordered and ordered alleles, was low, $G_{\mathrm{STC}}=0.29$ and $N_{\mathrm{STC}}=0.33$, respectively. The difference between $G_{\mathrm{STC}}$ and $N_{\text {STC }}$ is nonsignificant, indicating an absence of correlation between haplotype phylogeny and geographical distribution. The absence of phylogeographic structure in wild cherry may be attributed to long distance gene flow among populations by birds, animals and anthropogenic activities. The minimum-length spanning tree depicting the phylogenetic relationships between the haplotypes indicates the possible existence of two lineages represented by the haplotypes $\mathrm{H} 3$ and $\mathrm{H} 4$. The information about homogeneity or heterogeneity of populations in terms of haplotype constitution and detection of rare haplotypes in some populations will be useful for formulation of conservation and management strategies of wild cherry.
\end{abstract}

Keywords: cpDNA diversity, PCR-RFLP, phylogenetic relations, Prunus avium L., universal primers, wild cherry.

\section{Introduction}

Intraspecific chloroplast DNA (cpDNA) diversity is very useful in determining population structure and in phylogeographic studies (McCauley, 1995; Demesure et al., 1996; El Mousadik \& Petit, 1996; King \& Ferris, 1998; Dutech et al., 2000; Fineschi et al., 2000). Such studies have great implications for forest conservation and management (Newton et al., 1999). PCR-RFLP (polymerase chain reaction-restriction fragment length polymorphism) using universal primers (Taberlet et al., 1991; Demesure et al., 1995; Dumolin-Lapegue et al., 1997) has greatly facilitated the detection of intraspecific cpDNA variation. Fifty percent of such variations are attributable to small insertions and deletions (Gielly \& Taberlet, 1994).

Prunus avium L., commonly known as wild cherry, is an important noble hardwood species of European deciduous forests (Turok et al., 1996). It is an important

\footnotetext{
*Correspondence. E-mail: jpmartin@bio.etsia.upm.es
}

(c) 2001 The Genetics Society of Great Britain. timber, fruit and rootstock species. Furthermore, it is the wild ancestor of sweet cherry cultivars and has been used in genetic improvement programmes (Tydeman et al., 1966; Tobutt, 1985; Nicoll, 1993). The species is self-incompatible, insect-pollinated and seed dispersal is by animals, birds and humans (Crane \& Lawrence, 1931; Crane \& Brown, 1937). Nuclear genetic variability studies have been carried out in both cultivated and wild cherry (Frascaria et al., 1993; Beaver et al., 1995; Mariette et al., 1997). Mohanty et al. (2001) found low genetic differentiation among five wild cherry populations. However, these studies were limited by the number of populations (five to six) and distributional area investigated. The present investigation is the first attempt to present a more complete picture of cpDNA structuring in wild populations of $P$. avium by including 23 wild populations collected over a wide European range. The main objectives were to determine whether a phylogeographic structure exists in $P$. avium and to infer the phylogenetic relationships amongst the cpDNA haplotypes. 


\section{Materials and methods}

\section{Plant material}

Twenty-three wild populations of $P$. avium were sampled from deciduous forests across Europe (Table 1). Leaves were taken from mature trees located deep inside the forest, thus ensuring, to a large extent, that the trees had not been planted and were growing wild. The distance between sampled individuals in each population was at least $200 \mathrm{~m}$. Fresh leaves were collected from plants in the field, frozen and stored at $-80^{\circ} \mathrm{C}$.

\section{DNA extraction, amplification and digestion}

DNA was extracted from frozen leaves following the protocol of Torres et al. (1993), and then standardized $(4 \mathrm{ng} / \mu \mathrm{L})$.

The details of amplification and restriction digestion conditions are described in Mohanty et al. (2000, 2001). Five cpDNA primer pairs (HK, K1K2, CD, DT and VL; described in Dumolin-Lapegue et al., 1997) were used in the present study. Amplified products of these primers were digested with the restriction enzymes, HinfI and TaqI (Amersham). In addition, AluI was used with the primer pair VL. Restriction fragments were separated on $2.6 \%$ agarose gels in Tris-borate-EDTA buffer $(1 \times)$, run at $3 \mathrm{~V} / \mathrm{cm}$ for $4 \mathrm{~h}$, stained with ethidium bromide and visualized under UV light. Digests were also resolved on $8 \%$ polyacrylamide gels run in TBE buffer $(1 \times)$ at $350 \mathrm{~V}$ for $4-8 \mathrm{~h}$ (time depending on the size of fragment to be resolved); these gels were silver stained (Bassam et al., 1991). The size of the polymorphic bands were analysed using Kodak Digital Science 1D Image Analysis Software, and a 50-bp ladder (Pharmacia) was used as a molecular size marker.

\section{Analysis of data}

The program HaPlodiv (Pons \& Petit, 1995) was used to calculate the frequency of the haplotypes and estimate parameters of cpDNA diversity $\left(h_{\mathrm{T}}=\right.$ total diversity, $h_{\mathrm{S}}=$ average intrapopulation diversity, and $G_{\mathrm{STC}}=$ level of population subdivision using unordered alleles) and their standard errors. The program HAPLONST (Pons $\&$ Petit, 1996) was used to calculate $N_{\text {STC }}$ (level of population subdivision using ordered alleles).

The number of mutational differences between haplotypes of wild populations was calculated to produce a minimum-length spanning tree of haplotypes using NTSYS-pc (Rohlf, 1992). The procedure is used to connect points (haplotypes) by direct links having the

Table 1 Populations, origin and number of individuals studied in Prunus avium

\begin{tabular}{|c|c|c|c|c|}
\hline Code & Population & Origin & Longitude, Latitude & $\begin{array}{c}\text { No. of } \\
\text { individuals }\end{array}$ \\
\hline 01 & Glen Afric & Great Britain & $04^{\circ} 83^{\prime} \mathrm{W}, 57^{\circ} 32^{\prime} \mathrm{N}$ & 4 \\
\hline 03 & Forest of Dean & Great Britain & $02^{\circ} 65^{\prime} \mathrm{W}, 51^{\circ} 83^{\prime} \mathrm{N}$ & 10 \\
\hline 04 & Tofta & Sweden & $11^{\circ} 70^{\prime} \mathrm{E}, 57^{\circ} 87^{\prime} \mathrm{N}$ & 8 \\
\hline 05 & Stenshuvud & Sweden & $14^{\circ} 25^{\prime} \mathrm{E}, 55^{\circ} 65^{\prime} \mathrm{N}$ & 8 \\
\hline 07 & Bovenden & Germany & $10^{\circ} 05^{\prime} \mathrm{E}, 51^{\circ} 57^{\prime} \mathrm{N}$ & 11 \\
\hline 08 & Kelheim & Germany & $11^{\circ} 83^{\prime} \mathrm{E}, 48^{\circ} 93^{\prime} \mathrm{N}$ & 10 \\
\hline 09 & Fointainebleau & France & $02^{\circ} 67^{\prime} \mathrm{E}, 48^{\circ} 42^{\prime} \mathrm{N}$ & 9 \\
\hline 10 & Chizé & France & $00^{\circ} 40^{\prime} \mathrm{W}, 46^{\circ} 14^{\prime} \mathrm{N}$ & 10 \\
\hline 11 & Seillon & France & $05^{\circ} 00^{\prime} \mathrm{E}, 46^{\circ} 00^{\prime} \mathrm{N}$ & 10 \\
\hline 12 & Valbonne & France & $04^{\circ} 55^{\prime} \mathrm{E}, 44^{\circ} 24^{\prime} \mathrm{N}$ & 9 \\
\hline 17 & Parco Naz. Foreste Casentinesi & Italy & $11^{\circ} 80^{\prime} \mathrm{E}, 43^{\circ} 78^{\prime} \mathrm{N}$ & 10 \\
\hline 18 & Alto Garda Bresciano & Italy & $10^{\circ} 88^{\prime} \mathrm{E}, 45^{\circ} 80^{\prime} \mathrm{N}$ & 10 \\
\hline 19 & Park of Calabria & Italy & $16^{\circ} 58^{\prime} \mathrm{E}, 39^{\circ} 00^{\prime} \mathrm{N}$ & 10 \\
\hline 20 & Mt. Medvenica & Croatia & $15^{\circ} 95^{\prime} \mathrm{E}, 45^{\circ} 87^{\prime} \mathrm{N}$ & 4 \\
\hline 21 & Savarsin & Romania & $22^{\circ} 23^{\prime} \mathrm{E}, 46^{\circ} 02^{\prime} \mathrm{N}$ & 3 \\
\hline 22 & Boki & Slovakia & $19^{\circ} 12^{\prime} \mathrm{E}, 48^{\circ} 57^{\prime} \mathrm{N}$ & 13 \\
\hline 23 & Arnea & Greece & $23^{\circ} 60^{\prime} \mathrm{E}, 40^{\circ} 46^{\prime} \mathrm{N}$ & 10 \\
\hline
\end{tabular}


smallest possible total length (Prim, 1957). Minimum spanning networks are alternatives to Wagner parsimony trees, but better convey the connections between haplotypes (Excoffier \& Smouse, 1994).

\section{Results}

Five pairs of universal primers $(\mathrm{HK}, \mathrm{K} 1 \mathrm{~K} 2, \mathrm{CD}$, DT and VL) representing $13.2 \mathrm{~kb}$, approx. $9 \%$ of the chloroplast genome, were used for the complete survey. The sizes of the amplified products for $\mathrm{HK}, \mathrm{K} 1 \mathrm{~K} 2, \mathrm{CD}$, DT and VL were 1700 bp, 2650 bp, 3800 bp, 1150 bp and $3900 \mathrm{bp}$, respectively (Mohanty et al., 2001). Of the 11 primer-restriction enzyme combinations, 10 showed resolved polymorphic fragments (Table 2). Of a total of 67 resolved fragments, $41(60.1 \%)$ were polymorphic. All mutations were apparently insertion-deletions, except in the combination VL-TaqI where a point mutation was found (Table 2). Figure 1 shows representative restriction patterns observed in the combinations K1K2-HinfI and K1K2-TaqI. In all, 16 haplotypes were distinguished in the 23 populations (211 individuals). Ten haplotypes (H1, H2, H6, H9, $\mathrm{H} 10, \mathrm{H} 11, \mathrm{H} 12, \mathrm{H} 14, \mathrm{H} 15$ and H16) were unique to their respective populations, whereas the remaining six (H3, H4, H5, H7, H8 and H13) were shared by two or

Table 2 Majority patterns and variants (in $\mathrm{bp}$ ) in the polymorphic fragments obtained with different primerrestriction enzyme combinations in Prunus avium. A, B and $\mathrm{C}$ are the haplotypes in each polymorphic fragment. Combinations of $\mathrm{A}, \mathrm{B}$ and/or $\mathrm{C}$ produce the final haplotypes (H1 to H16, see text)

\begin{tabular}{|c|c|}
\hline $\begin{array}{l}\text { Polymorphic } \\
\text { fragments }\end{array}$ & Majority $\rightarrow$ Variant \\
\hline HK-HinfI & $250(\mathrm{~A}) \rightarrow 240(\mathrm{~B})$ \\
\hline K1K2-(HinfI)1 & $190(\mathrm{~B}) \rightarrow 195(\mathrm{~A})$ \\
\hline $\mathrm{K} 1 \mathrm{~K} 2-(\operatorname{HinfI}) 2$ & $175(\mathrm{~B}) \rightarrow 180(\mathrm{~A}), 170(\mathrm{C})$ \\
\hline K1K2-(TaqI)1 & $340(\mathrm{~B}) \rightarrow 350(\mathrm{~A})$ \\
\hline $\mathrm{K} 1 \mathrm{~K} 2-(\operatorname{Taq} \mathrm{I}) 2$ & $270(\mathrm{~A}) \rightarrow 265(\mathrm{~B})$ \\
\hline $\mathrm{K} 1 \mathrm{~K} 2-(\operatorname{Taq} \mathrm{I}) 3$ & $195(\mathrm{~B}) \rightarrow 205(\mathrm{~A}), 190(\mathrm{C})$ \\
\hline CD- $(H i n \mathrm{fI}) 1$ & $0(\mathrm{~B}) \rightarrow 530(\mathrm{~A})$ \\
\hline CD- $($ HinfI $) 2$ & $220(\mathrm{~A}) \rightarrow 210(\mathrm{~B})$ \\
\hline CD- $(\operatorname{Taq} \mathrm{I}) 1$ & $850(\mathrm{~A}) \rightarrow 600(\mathrm{~B})$ \\
\hline $\mathrm{CD}-(\operatorname{Taq} \mathrm{I}) 2$ & $330(\mathrm{~A}) \rightarrow 315(\mathrm{~B})$ \\
\hline DT- $(H i n \mathrm{fI}) 1$ & $300(\mathrm{~B}) \rightarrow 310(\mathrm{~A})$ \\
\hline DT-(HinfI $) 2$ & $275(\mathrm{~A}) \rightarrow 270(\mathrm{~B})$ \\
\hline DT-(TaqI)1 & $550(\mathrm{~B}) \rightarrow 555(\mathrm{~A})$ \\
\hline DT-(TaqI)2 & $400(\mathrm{~B}) \rightarrow 410(\mathrm{~A}), 395(\mathrm{C})$ \\
\hline VL-(AluI $) 1$ & $1050(\mathrm{~A}) \rightarrow 900(\mathrm{~B})$ \\
\hline VL-(AluI $) 2$ & $550(\mathrm{~B}) \rightarrow 625(\mathrm{~A})$ \\
\hline VL-HinfI & $380(\mathrm{~B}) \rightarrow 390(\mathrm{~A})$ \\
\hline $\mathrm{VL}-\operatorname{Taq\mathrm {I}}$ & $1600(\mathrm{~B}) \rightarrow 1700(\mathrm{~A}), 1200+400(\mathrm{C})$ \\
\hline
\end{tabular}

(C) The Genetics Society of Great Britain, Heredity, 87, 421-427. more populations (Table 3 ). $\mathrm{H} 3$ is the most frequent (0.73) and abundant haplotype, being present in 21 of the 23 populations; it is absent in two of the eastern populations (21, Romania and 23, Greece; Table 3). Populations 02, 03 (Great Britain), 09, 10, 13 (France) and 17 (Italy) were monomorphic for haplotype H3. Populations 04, 05 (Sweden), 06, 07 (Germany), 09, 10, 11, 12, 13 (France), 14, 16 (Spain), 18 (Italy), 20 (Croatia), 21 (Romania) and 23 (Greece) contained no unique haplotypes. The maximum number of haplotypes (five) occurred in population 19 (Italy), of which three were unique, followed by population 15 (Spain) with four haplotypes, of which three were unique (Table 3).

A major proportion of the total diversity $\left(h_{\mathrm{T}}=0.46\right)$ is contributed by intrapopulation diversity $\left(h_{\mathrm{S}}=0.33\right.$; Table 4). The level of population subdivision using unordered and ordered alleles were $G_{\mathrm{STC}}=0.29$ and $N_{\mathrm{STC}}=0.33$, respectively. The difference between $N_{\mathrm{STC}}$ and $G_{\text {STC }}$ was nonsignificant $(U$-test $=0.35, P=0.05$, according to Pons \& Petit, 1996).

The minimum-length spanning tree showing the phylogenetic relationships between the 16 haplotypes is shown in Fig. 2. Haplotypes $\mathrm{H} 3$ and $\mathrm{H} 4$ form two nodes of the tree and are linked by the haplotypes $\mathrm{H} 5$ and $\mathrm{H} 7$, each differing from the adjacent haplotypes by a single mutation. The private haplotypes, H2, H6, H11 and $\mathrm{H} 16$, are related to node $\mathrm{H} 3$, whereas the haplotypes of population 19 (i.e. H12, H13, H14 and H15), two private haplotypes of population 15 (H9 and $\mathrm{H} 10)$ and $\mathrm{H} 1$ of population 01 are linked to node $\mathrm{H} 4$. The shared haplotype, $\mathrm{H} 8$, is also related to node $\mathrm{H} 4$.

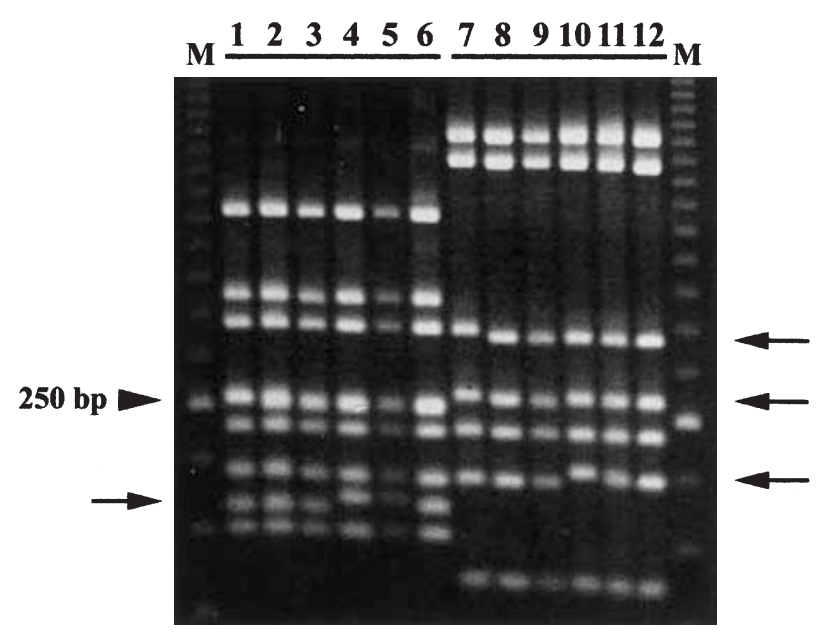

Fig. 1 Restriction patterns of primer-enzyme combinations K1K2-HinfI (1-6) and K1K2-TaqI (7-12), resolved on agarose gel. $\mathrm{M}$ indicates the molecular size marker (50 bp ladder, Pharmacia). Arrows indicate the polymorphic sites detected. 


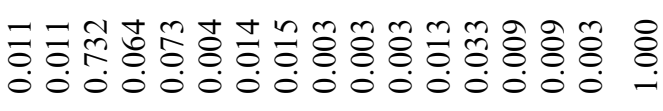

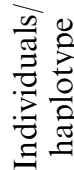

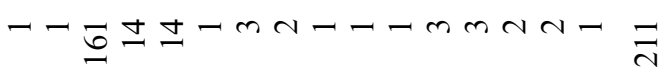
$=$

$000-9000000000000$ 00 N000000000000-n $\overrightarrow{\mathrm{N}} 0000-0000000 \mathrm{NO0} \mathrm{m}$ ก $00 m 0000-00000000 \%$

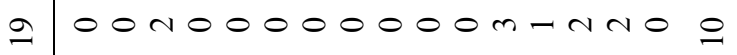
$\leadsto 000-0000000000000$ $=00000000000000000$ - $00 m n 0000000000000$

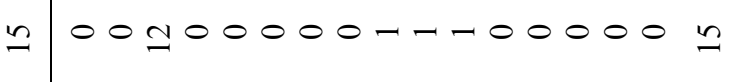
I $0000000-000000000$ th $=00000000000000000$ II $=00-00 N 000000000 a$ a $=000-0000000000000$ - 00000000000000000 800000000000000000 $\%$ OONNOH-000000000? 5 $00 a-100000000000=$ \& oonn-00000000000? a $00+n n 00000000000 \infty$ I OOn-000000000000 m 00000000000000000 d oon $0000000000000 \mathrm{n}$ $0-70000000000000 \%$ 
Table 4 Results of the analysis of diversity in populations of Prunus avium; standard errors of the estimates are in parentheses

\begin{tabular}{lcccccccc}
\hline $\begin{array}{l}\text { No. of } \\
\text { populations }\end{array}$ & $\begin{array}{c}\text { Arithmetic } \\
\text { mean }\end{array}$ & $\begin{array}{c}\text { Harmonic } \\
\text { mean }\end{array}$ & $h_{\mathrm{S}}$ & $h_{\mathrm{T}}$ & $G_{\text {STC }}$ & $v_{\mathrm{S}}$ & $v_{\mathrm{T}}$ & $N_{\text {STC }}$ \\
\hline 23 & 9.17 & 7.98 & $0.33(0.06)$ & $0.46(0.09)$ & $0.29(0.09)$ & $0.31(0.08)$ & $0.46(0.14)$ & $0.33(0.06)$ \\
\hline
\end{tabular}

Fig. 2 Minimum-length spanning tree of 16 cpDNA haplotypes of Prunus avium from 23 European deciduous forests. Each asterisk represents one restriction pattern difference between haplotypes

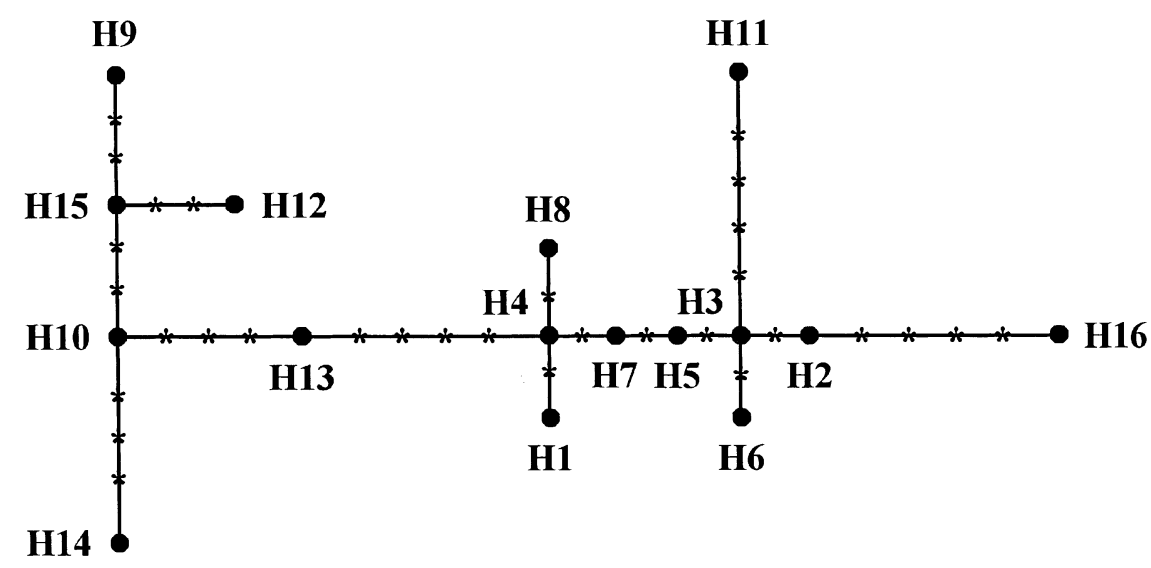

\section{Discussion}

A survey of 23 populations of wild cherry (which includes five populations: 01, 08, 10, 16 and 17 studied by Mohanty et al., 2001) spread over a wide European range, revealed $16 \mathrm{cpDNA}$ haplotypes. Total cpDNA diversity $\left(h_{\mathrm{T}}\right)$ in the present study was slightly more $\left(h_{\mathrm{T}}=46 \%\right)$ than a previous study of $P$. $\operatorname{avium}\left(h_{\mathrm{T}}=40 \%\right)$ involving five populations (Mohanty et al., 2001). The level of population subdivision using unordered alleles was low $\left(G_{\mathrm{STC}}=0.29\right)$ compared to the average $G_{\mathrm{STC}}=0.70$ for 97 plant species (Petit, 1999). Some species, such as Argania spinosa $\left(G_{\mathrm{STC}}=0.60\right.$, El Mousadik \& Petit, 1996), Quercus petraea $\left(G_{\mathrm{STC}}=0.90\right.$, Petit et al. 1993a) and Fagus sylvatica $\left(G_{\mathrm{STC}}=0.83\right.$, Demesure et al., 1996), with animal-dispersed seed have limited cytoplasmic gene flow and hence high $G_{\text {STC }}$ values. The low $G_{\text {STC }}$ in wild cherry indicates efficient cytoplasmic gene flow among populations, leading to decreased genotypic heterogeneity between them. Long distance seed dispersal by birds and humans appear to be the source of such gene flow between populations. Anthropogenic activities have much more impact on seeds produced by an edible plant species, and when supplemented by seed dispersal by birds and animals, the cytoplasmic gene flow may be higher than expected. Similarly, seed dispersal in the edible species Castanea sativa is strongly influenced by humans and has a comparatively low $G_{\mathrm{STC}}$ value of 0.43 (Fineschi et al., 2000). Nuclear gene flow in this species is even higher than cytoplasmic gene flow, $G_{\mathrm{STN}}=0.05$ (Frascaria et al., 1993) and $G_{\mathrm{STN}}=0.06$ (Mariette et al., 1997). This is expected as cytoplasmic markers [maternally inherited in most angiosperms (Birky, 1995), hence gene flow is limited to seed dispersal] are theoretically expected to reveal more differentiation among populations than nuclear markers (Petit et al. 1993b). The level of population subdivision using ordered alleles was slightly higher $\left(N_{\mathrm{STC}}=0.33\right)$ than $G_{\mathrm{STC}}$ but the difference was not significant, which indicates the absence of a relationship between phylogeny and the geographical distribution of haplotypes (Pons \& Petit, 1996).

The minimum-length spanning tree of haplotypes did not show any phylogeographic structure; however, the phylogenetic relationships between the haplotypes could be analysed (Fig. 2). Haplotypes $\mathrm{H} 3$ and $\mathrm{H} 4$ (the most widely distributed haplotypes) appear as two nodes of the tree. $\mathrm{H} 3$ is present in 21 and $\mathrm{H} 4$ in 10 of the 23 populations. Hence, they possibly represent two lineages. However, there is a big disparity in their frequencies ( $\mathrm{H} 3,0.73$; and $\mathrm{H} 4,0.06)$; an inference from this could be that $\mathrm{H} 3$ represents a more ancient lineage, whereas $\mathrm{H} 4$ is of comparatively recent origin. If this is so, then it would be more appropriate to term $\mathrm{H} 4$ a subnode.

Following this, subnode $\mathrm{H} 4$ harbours all the haplotypes of population 19, Italy (H12, H13, H14, H15), of which one (H13) is shared by population 21 (Romania). Two unique haplotypes (H9, H10) of population 15 (Spain), haplotype H8 shared by populations 14 (Spain) and 20 (Croatia) and one unique haplotype (H1) of population 01 (Great Britain) are also related to 
subnode H4. Haplotype $\mathrm{H} 4$ is absent in all these populations.

Haplotype $\mathrm{H} 13$ is linked to $\mathrm{H} 4$ by four mutations and the rest of the haplotypes of this lineage (except $\mathrm{H} 1$ and H8) are relatively distantly related to each other (two to three mutational differences) and to H4. Similarly, the unique haplotypes $\mathrm{H} 11$ and $\mathrm{H} 16$ are four and five mutations away from the node $\mathrm{H} 3$, respectively. The larger number of mutational differences of rare haplotypes from nodes $\mathrm{H} 3$ and $\mathrm{H} 4$ may be due to missing haplotypes which may link the rare haplotypes further to their respective nodes or to each other. A more intensive sampling may locate these 'missing' haplotypes. The low frequencies of the unique haplotypes probably reflect their recent origin.

Population 23 (Greece) is dominated by haplotype $\mathrm{H} 5$, and $\mathrm{H} 3$ (the most common haplotype) is absent from this population. These two haplotypes differ by a single mutation. It is probable that $\mathrm{H} 5$ proceeds from $\mathrm{H} 3$ but over the course of time $\mathrm{H} 5$ gained selective advantage over $\mathrm{H} 3$ leading to its dominance and disappearance of $\mathrm{H} 3$.

Haplotype diversity in Italian and Iberian populations is high with 10 different haplotypes, of which three are unique to population 19 (Italy) and another three to population 15 (Spain). On the other hand, only five haplotypes are found in northern Europe populations (Great Britain and Sweden), of which two are unique to population 01 (Great Britain). These two unique haplotypes ( $\mathrm{H} 1$ and $\mathrm{H} 2$ ) could be cultivated forms of wild cherry since it was later found (Dr Richard Ennos, personal communication) that this population was an artificial population with the possibility of the occurrence of cultivated $P$. avium among the wild trees. A previous study had revealed that haplotypes of cultivars and wild $P$. avium were different (Mohanty et al., 2001). Hence, the number of haplotypes in populations from Great Britain and Sweden is reduced to three. This decrease in haplotype heterogeneity from south to north of Europe is in agreement with other studies (Mohanty et al., 2000; Demesure et al., 1996; King \& Ferris, 1998).

From the present study, it is not possible to predict any migration routes for $P$. avium. This is because one haplotype (H3) is very abundant and is common to almost all the populations; the other shared haplotypes are present at low frequency and with sporadic occurrence in populations. Furthermore, no fossil pollen data are available for this species.

The study throws light on cpDNA haplotype distribution of $P$. avium in the European deciduous forests. Genetically polymorphic populations and unique haplotypes which give special features to the populations have been identified; this information could provide important guidelines for staging conservation and management strategies in this tree species.

\section{Acknowledgements}

We are thankful to Dr Remy J. Petit for providing us with the universal primers and the HAPLODIV and HAPLONST programs. The research was supported by the EC research programme FAIR5-CT97-3795.

\section{References}

BASSAM, B. J., CAETANO-ANOLLÉS, G. AND GRESSHOFF, P. M. 1991. Fast and sensitive silver staining of DNA in polyacrylamide gels. Analyt. Biochem., 80, 81-84.

BEAVER, J. F., IEZZONI, A. F. AND RAMM, C. W. 1995. Isozyme diversity in sour, sweet and ground cherry. Theor. Appl. Genet., 90, 847-852.

BIRKY, C. JR. 1995. Uniparental inheritance of mitochondrial and chloroplast genes: mechanisms and evolution. Proc. Natl. Acad. Sci. U.S.A., 92, 11331-11338.

CRANE, M. B. AND BROWN, A. G. 1937. Incompatibility and sterility in the sweet cherry, Prunus avium L. J. Pomol. Hort. Sci., 15, 80-116.

CRANE, M. B. AND LAWRENCE, W. J. C. 1931. Sterility and incompatibility in diploid and polyploid fruits. J. Genet., 24, 97-107.

DEMESURE, B., SODZI, N. AND PETIT, R. J. 1995. A set of universal primers for amplification of polymorphic non-coding regions of mitochondrial and chloroplast DNA in plants. Mol. Ecol., 4, 129-131.

DEMESURE, B., COMPS, B. AND PETIT, R. J. 1996. Chloroplast DNA phylogeography of the common beech (Fagus sylvatica L.) in Europe. Evolution, 50, 2515-2520.

DUMOLIN-LAPEGUE, S., PEMONGE, M.-H. AND PETIT, R. J. 1997. An enlarged set of consensus primers for the study of organelle DNA in plants. Mol. Ecol., 6, 393-397.

DUTECH, C., MAGGIA, L. AND JOLY, H. I. 2000. Chloroplast diversity in Vouacapoua americana (Caesalpiniaceae), a neotropical forest tree. Mol. Ecol., 9, 1427-1432.

EL MOUSADIK, A. AND PETIT, R. J. 1996. Chloroplast DNA phylogeography of the argan tree of Morocco. Mol. Ecol., 5, 547-555.

EXCOFFIER, L. AND SMOUSE, P. E. 1994. Using allele frequencies and geographic subdivision to reconstruct gene trees within a species: molecular variance parsimony. Genetics, 136, 343-359.

FINESCHI, S., TAURCHINI, D., VILLANI, F. AND VENDRAMIN, G. G. 2000. Chloroplast DNA polymorphism reveals little geographical structure in Castanea sativa Mill. (Fagaceae) throughout southern European countries. Mol. Ecol., 9, 1495-1503.

FRASCARIA, N., SANTI, F. AND GOUYON, P. H. 1993. Genetic differentiation within and among populations of chestnut (Castanea sativa Mill.) and wild cherry (Prunus avium L.). Heredity, 70, 634-641. 
GIELLY, L. AND TABERLET, P. 1994. The use of chloroplast DNA to resolve plant phylogenies: non-coding vs. $r b c l$ sequences. Mol. Biol. Evol., 11, 769-777.

KING, R. A. AND FERRIS, C. 1998. Chloroplast DNA phylogeography of Alnus glutinosa (L.) Gaertn. Mol. Ecol., 7, 1151-1161.

MARIETTE, S., LEFRANC, M., LEGRAND, P., TANEYHILl, D. et al. 1997. Genetic variability in wild cherry populations in France. Effects of colonizing processes. Theor. Appl. Genet., 94, 904-908.

MCCAULEY, D. E. 1995. The use of chloroplast DNA polymorphism in studies of gene flow in plants. Trends Ecol. Evol., 10, 198-202.

MOHANTY, A., MARTín, J. P. AND AGUinAgALDE, I. 2000. Chloroplast DNA diversity within and among populations of the allotetraploid Prunus spinosa L. Theor. Appl. Genet., 100, 1304-1310.

MOHANTY, A., MARTín, J. P. AND AGUINAGALDE, I. 2001. Chloroplast DNA study in wild populations and some cultivars of Prunus avium L. Theor. Appl. Genet., 103, 112117.

NeWton, A. C., Allnutt, T. R., Gillies, A. C. M., LOWE, A. J. et al. 1999. Molecular phylogeography, intraspecific variation and the conservation of tree species. Trends Ecol. Evol., 14, 140-145.

NICOLL, F. J. 1993. Genetic improvement of cherry for farm woodlands. Quart. J. For., 87, 187-194.

Petit, R. J. 1999. Diversité Génétique et Histoire des Populations $d^{\prime}$ Arbres Forestiers. Dossier d'habilitation a diriger des recherches, Université de Paris-Sud, Université Formation de Recherche Scientifique d'Orsay, Paris.

PETIT, R. J., KREMER, A. AND WAGNER, D. B. 1993a. Geographic structure of chloroplast DNA polymorphisms in European oaks. Theor. Appl. Genet., 87, 122-128.
PETIT, R. J., KREMER, A. AND WAGNER, D. B. 1993b. Finite island model for organelle and nuclear genes in plants. Heredity, 71, 630-641.

PONS, O. AND PETIT, R. J. 1995. Estimation, variance and optimal sampling of gene diversity 1. Haploid locus. Theor. Appl. Genet., 90, 462-470.

PONS, O. AND PETIT, R. J. 1996. Measuring and testing genetic differentiation with ordered versus unordered alleles. Genetics, 144, 1237-1245.

PRIM, R. C. 1957. Shortest connection networks and some generalizations. Bell Labs. Tech. J., 36, 1389-1401.

ROHLF, F. J. 1992. NTSYS-pc: Numerical taxonomy and multivariate analysis system, version 1.60. Exeter Software, New York.

TABerlet, P., GIElly, L., PAUtou, G. AND BOUVET, J. 1991. Universal primers for amplification of three non-coding regions of chloroplast DNA. Plant Mol. Biol., 17, 11051109.

TOBUTT, K. R. 1985. New approaches to breeding sweet cherry scion varieties at East Malling, with particular reference to small tree size. Acta. Hort., 169, 43-50.

TORRES, A. M., WEEDEN, N. F. AND MARTín, A. 1993. Linkage among isozyme, RFLP and RAPD markers in Vicia faba. Theor. Appl. Genet., 85, 937-945.

TUROK, J., ERIKSSON, G. AND KLEINSChMit, J. 1996. Noble hardwoods network. Report of the first meeting, 24-27 March, Escherode, Germany. International Plant Genetic Resources Institute, Rome.

TYDEMAN, H. M. AND GARNER, R. J. 1966. Breeding and testing rootstocks for cherries. Rep. East Malling Res. Stn. for 1965, pp. $130-154$. 